Research article

\title{
FIRST DETECTION AND CLINICAL PRESENTATION OF PORCINE EPIDEMIC DIARRHEA VIRUS (PEDV) IN SERBIA
}

\author{
PRODANOV-RADULOVIĆ Jasna*, PETROVIĆ Tamaš, LUPULOVIĆ Diana, \\ MARČIĆ Doroteja, PETROVIĆ Jelena, GRGIĆ Živoslav, LAZIĆ Sava
}

Scientific Veterinary Institute „Novi Sad“, Novi Sad, Serbia

(Received 23 January, Accepted 13 December 2016)

During 2015/2016, fecal and intestinal samples from live diseased and/or dead pigs with suspected PEDV and/or TGEV and signs of rotavirus infection were collected from in total seven different farrow-to-finish swine farms located in Northern Serbia region (Vojvodina Province). A total of 14 samples (2 pools per farm) of small intestine with fecal content were submitted to laboratory molecular investigation (multiplex RTPCR). On these farms the clinical signs included the occurrence of diarrhea in suckling and weaned piglets, with weak or no response to the applied antimicrobial therapy. The epidemic of severe diarrhea affecting pigs of all ages on one farrow-to finish swine farm was detected in January 2016. Watery diarrhea in all swine categories was associated with vomiting and a reduction in feed consumption. Diarrheic, gaunt and dehydrated piglets, covered with feces were found in $90 \%$ litters. The disease affected most severely the suckling piglets, and the mortality in newborn piglets was up to $35 \%$. In the weaned piglets and fatteners the mortality was up to $2.5 \%$ and $1.2 \%$, respectively. The PEDV RNA was detected in pooled feces and samples of small intestines derived from diseased and dead suckling piglets from only one investigated farm. The PEDV positive samples showed to be negative for rotavirus group A and TGEV. The transport vehicles were identified as the main possible route of PEDV introduction. This is the first report demonstrating the presence of PEDV in Serbia.

Key words: Porcine epidemic diarrhea virus (PEDV), swine farm, Serbia

\section{INTRODUCTION}

Porcine epidemic diarrhea virus (PEDV) is an enveloped single-stranded positive sense RNA virus, a member of the order Nidovirales, family Coronaviridae, genus Alphacoronavirus [1-3]. It causes an acute, highly contagious enteric disease of pigs of all ages with typical clinical symptoms of watery diarrhea, vomiting, weight loss and severe dehydration [4,5]. The clinical outcome is a malabsorptive diarrhea, which is a consequence of the viral infection and atrophy of the small intestinal villi [1]. Dehydration is exacerbated by vomiting, but the mechanisms by which vomiting is

\footnotetext{
*Corresponding author: e-mail: jasna@niv.ns.ac.rs
} 
induced in PEDV infection are poorly understood [6]. Mortality in suckling piglets less than two weeks old may vary from 0 to $100 \%$. Up to now, there is no information available on the potential origin of this virus [5]. Only one serotype of PEDV has been reported from different countries $[1,6]$.

The first clinical description of the disease occurred in the United Kingdom (UK) in 1971 and later in 1976 in Belgium [1,5]. The disease was initially termed "epidemic viral diarrhea" due to the quick spread across Europe [4,7]. Since the first description of the disease, within the next two decades, PEDV was reported in several other European countries including Hungary, Italy, Germany, France, Switzerland, and Czech Republic causing only isolated outbreaks [2,8-10]. During the 1980s and 1990s, outbreaks of porcine epidemic diarrhea (PED) appeared in European pigs infrequently, but the virus continued to spread and persisted in an endemic form in the pig population $[8,11]$. In Asia, PEDV was first identified in 1982 and is now considered endemic, causing devastating enteric diseases and substantial economic losses to the pork industry [6]. The virus appeared for the first time in the United States of America (USA) in 2013 [12]. Shortly after its first detection, in 2014, a novel PEDV variant strain OH851 (called INDEL strains) was isolated in the USA, which was associated with the milder disease symptoms and low mortality in suckling piglets [13,14]. After the emergence of PED in the USA, sequence analyses revealed high nucleotide identity between North American and Asian PEDV strains suggesting a common ancestor for PEDV in both continents [15].

Over the last ten years only sporadic outbreaks have been reported in Europe, thus requiring no active monitoring of PEDV [6,15]. The only well documented is a typical PED epidemic in Europe which occurred during the winter of 2005-2006 in Northern Italy [16]. Recently, the PED-confirmed outbreaks have been reported in several Central European countries: Portugal [7], Germany [15], Austria [17], France [18], Belgium [19], Ukraine [20], Italy [21] and Slovenia [22]. The full genome sequencing of recent PEDV strains from Germany, Belgium and France [17-19] shows that they are all highly similar and closely related to S-INDEL strains from USA $[9,13]$. Also, the virus recovered from PED outbreaks in Austria and Slovenia [15,22] is almost identical to other currently circulating PEDV from Western and Central Europe, which suggests a common source of introduction [17]. This may suggest that INDEL strains circulate in Europe for a longer time than was previously hypothesized $[9,18]$. However, fairly little information on the current situation on PED is available from the rest of the European countries, especially in the neighboring countries of Serbia.

In the present work we are reporting the first detection of PEDV in early 2016 in pigs on one Serbian farrow-to-finish swine farm located in Vojvodina Province and provide information about clinical symptoms, gross pathology, molecular diagnostic test results and possible route of PEDV entry. 


\section{MATERIAL AND METHODS}

\section{History of swine farm data and collection of samples}

During 2015/2016 we collected fecal and intestinal samples from live diseased and/ or dead pigs with suspected PEDV and/or transmissible gastroenteritis virus (TGEV) and rotavirus signs of infections. On these farms the clinical signs included occurrence of diarrhea in suckling and weaned piglets, with a weak or no response to the applied antimicrobial therapy. The samples originated from seven different farrow-to-finish swine farms (A, B, C, D, E, F, G) located in Northern Serbia region (Vojvodina Province). A total of 14 samples (2 pools per swine farm) of small intestine with the fecal content where submitted to further molecular laboratory investigation.

Among these farms, in January 2016, one farrow-to-finish pig farm (capacity of 1200 saws), located in the Srem district of Vojvodina Province reported the occurrence of severe clinical diarrhea and vomiting in all swine categories. Upon farm visiting, the morbidity and mortality data of all swine categories were noted. After clinical inspection, the gross pathology investigation which included in total 35 dead suckling and 15 weaned piglets was done.

\section{Molecular detection and characterization}

In a total 14 samples of small intestine with fecal content from seven farrow-to-finish swine farms ( 2 samples per each farm) were processed for virus detection. About $0.5 \mathrm{~g}$ of small intestine samples was dissected with scissors in small pieces and together with $1 \mathrm{~g}$ of fecal content were homogenized with the TissueLyser LT (Qiagen, Germany). The lysates were re-suspended as 10\% suspension in PBS and further used for RNA extraction. Viral RNA was extracted using the commercial ISOLATE II RNA Mini Kit (Bioline, The Netherlands) according to the manufacturer's instruction.

Detection of PEDV was done by conventional multiplex reverse transcription polymerase chain reaction (RT-PCR), with primers that simultaneously could detect and distinguish PEDV, TGEV and rotaviruses in pigs previously described by Song et al. [23]. For amplification, the commercial OneStep RT-PCR kit (Qiagen, Germany) was used with primers that amplified the $651 \mathrm{bp}$ fragment of spike protein (S) gene of PEDV (P1 (TTCTGAGTCACGAACAGCCA, 1466-1485) and P2 (CATATGCAGCCTGCTCTGAA, 2097-2116)), 859 bp fragment of $\mathrm{S}$ gene of TGEV (T1 (GTGGT'TT'TGGTYRTAAATGC, 16-35) and T2 (CACTAACCAACGTGGARCTA, 855-874)), and 309 bp fragment of gene segment 6 of porcine group A rotavirus (rot3 (AAAGATGCTAGGGACAAAATTG, 57-78) and rot5 (TTCAGATTGTGGAGCTATTCCA, 344-365)) as described by Song et al. [23]. Briefly, the reaction was performed in a total volume of $25 \mu \mathrm{l}$ as follows: $8 \mu \mathrm{l}$ of nuclease free water, $5 \mu \mathrm{l}$ of $5 \mathrm{x}$ PCR buffer, $1 \mu \mathrm{l}$ of dNTP mix (containing $10 \mathrm{mM}$ of each dNTP), $1 \mu \mathrm{l}$ of $20 \mu \mathrm{M}$ solution of each primer, $1 \mu \mathrm{l}$ of one step RT-PCR enzyme mix and $4 \mu \mathrm{l}$ of RNA template. RT-PCR protocol comprised reverse transcription 
at temperature $50^{\circ} \mathrm{C}$ for 30 minute followed with initial denaturation at $95^{\circ} \mathrm{C}$ for 15 minutes. After this step, PCR consisted of 40 repeated cycles of denaturation at $94^{\circ} \mathrm{C}$ for $30 \mathrm{sec}$, annealing at $55^{\circ} \mathrm{C}$ for $60 \mathrm{sec}$ and elongation at $72^{\circ} \mathrm{C}$ for $60 \mathrm{sec}$. the process was finalized with final elongation at $72^{\circ} \mathrm{C}$ for 10 minutes. The presence of the specific 859 bp product for TGEV, 651 bp product for PEDV, and 309 bp product for rotavirus detected by agarose gel electrophoresis was considered as a positive result. Positive results were further confirmed by sequencing of PCR products.

\section{RESULTS}

\section{Farm history data and clinical findings}

On the six investigated swine farms (A, B, C, D, E, F), data regarding pigs' health were evaluated. No clinical signs of diarrhea and/or vomiting in adult swine categories (gilts, sows, boars, fatteners) were detected. As regard to piglets' health parameters, approximately $28 \%$ of diseased suckling and/or weaned piglets showed mild growth retardation, dehydration and diarrhea or mashed feces.

According to veterinary data on farm $G$, watery greyish diarrhea and reduced feed intake firstly occurred in the category of young fatteners. During the first days, approximately $30-50 \%$ of fatteners were affected. Feces contained undigested feed components but no mucus or blood. No vomiting was observed and in this category mortality reached $1.2 \%$. The disease in fatteners lasted for 10 to 15 days. However, several days after the occurrence of the disease in fatteners, similar clinical signs were detected in pregnant and lactating sows. Pasty to watery diarrhea and vomiting firstly occurred in the gestation unit. Three to four days after the first onset of the disease, up to $90 \%$ of the sows in the farrowing unit were affected by watery diarrhea, reduced to absent feed intake (anorexia) and vomiting (Figure 1 and 2). When the next group of sows farrowed, the piglets from these sows were acutely affected and started to show yellowish, pasty diarrhea one to two days after birth. Pasty diarrhea progressed to watery feces with variable degrees of dehydration, affecting about $90 \%$ of suckling piglets from one farrowing room (Figure 3). The most severely affected piglets were 3 to 5 days of age. Watery diarrhea with a small amount of mucus and without blood and frequent vomiting was associated with weight loss and severe dehydration. The diarrhea in suckling piglets did not respond to the applied antibiotic treatment and had escalated in the next few days, encompassing most of the piglets in the affected farrowing rooms. In the first days, the mortality in suckling piglets was up to $35 \%$. Within five to seven days after the onset of clinical signs in suckling piglets, weaned piglets developed diarrhea accompanied by anorexia, varying degrees of weight loss and dehydration. In weaned piglets the morbidity ranged from 20 to 30\%, but there was either no mortality or it was low (1.6-2.5\%). Within three weeks after the onset of first clinical signs, diarrhea had spread to all age groups of pigs present at the farm, including boars. Clinical signs lasted for approximately five weeks and performance 
data returned to normal within seven weeks after the initial outbreak of PED. At the peak of clinical signs, the feed consumption rapidly declined in all categories. The disease was most severe among piglets less than 7 days of age and it was decided to euthanize the most dehydrated piglets. Piglets older than 14 days of age became sick, but most of them survived after applying intensive rehydration measures. The disease was less severe in adults, whose appetite returned and diarrhea ceased within 15 days.

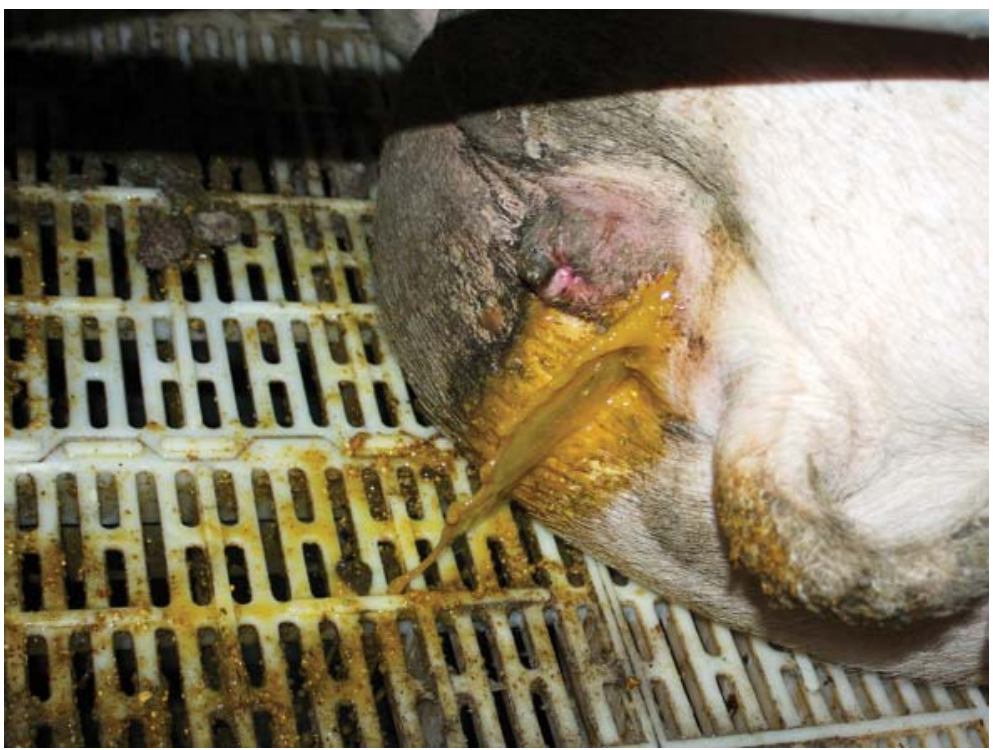

Figure 1. Clinical signs of PEDV-infected sows: watery diarrhea

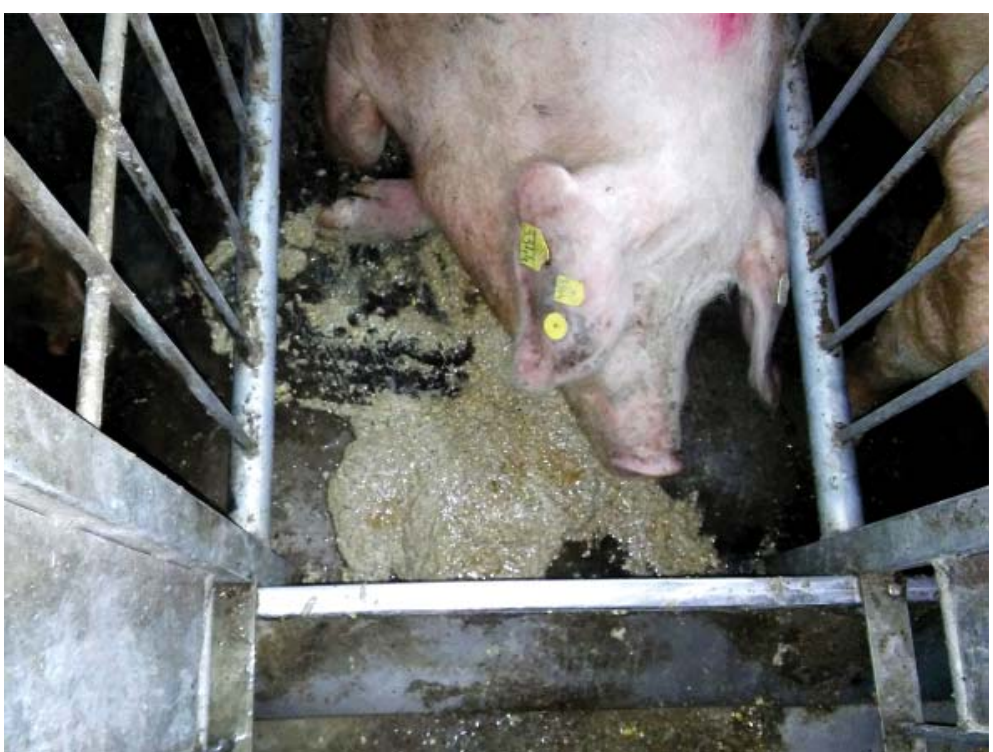

Figure 2. Clinical signs of PEDV-infected sows: vomiting 


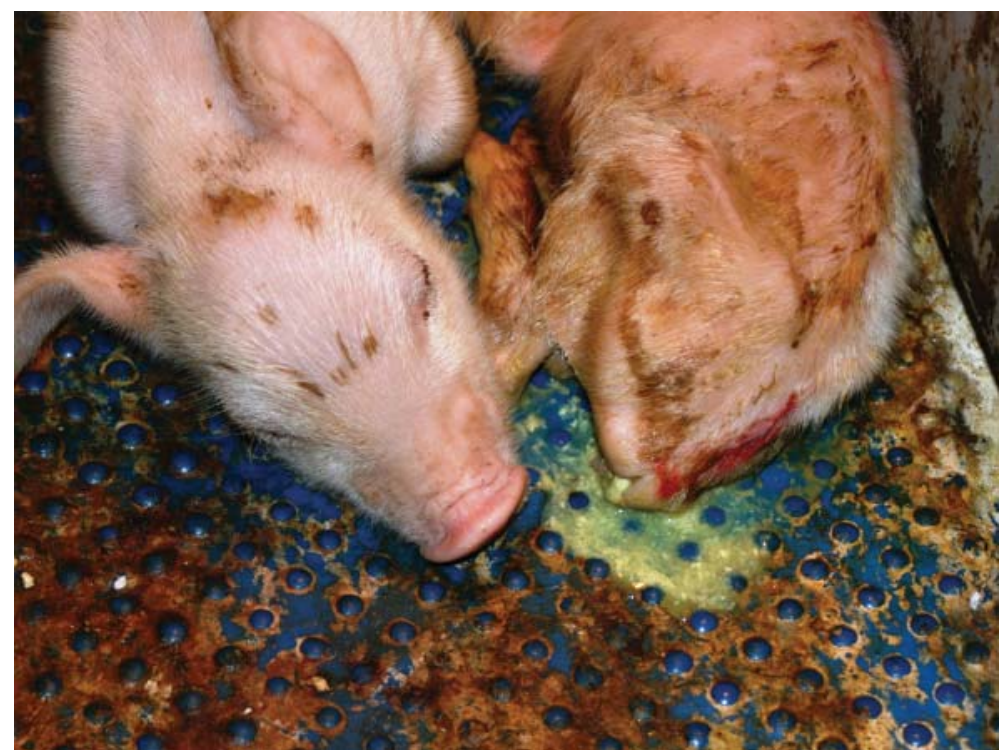

Figure 3. Diarrhea in PEDV-infected piglets

The reproduction status of sows was not substantially affected and no higher return rate or abortions were observed. However, clinically diseased postpartum sows had a reduced feed intake and associated reduced milk output (agalactia).

\section{Gross pathology findings}

In six investigated swine farms (A, B, C, D, E, F), based on the lesions detected by gross pathology (Enteritis haemorrhagica, Enteritis necroticans porcellarum), approximately $52 \%$ of total diarrhea cases were attributed to primarily and/or secondary bacterial enteric infection (Escherichia coli, Clostridium perfringens).

Regarding the investigated swine farm G, in total 35 dead suckling and 15 weaned piglets were submitted to autopsy. The suckling and weaned piglets ranged in age from $2-7$ and $15-25$ days, weight from 0.8 to $1.3 \mathrm{~kg}$ and 3.5 to $6.5 \mathrm{~kg}$, respectively. Gross pathological findings were similar in all suckling piglets. The skin was mostly ( $80 \%$ of body area) covered with yellowish, dried feces (Figure 4). Body condition appeared adequate for their age but with signs of severe dehydration: the skin was like a parchment, distinctly wrinkled in the main joints areas. Gross lesions were limited to the small intestines and characterized by distended, thin and transparent intestinal walls. The intestinal lumen contained yellow, watery fluid with a lot of mucus (Figure 5). In individual pigs intestinal contents were completely absent or the intestine (jejunum) was dilated by gas and there was an accumulation of watery contents. Lack of intestinal lacteals, as an indicator of malabsorption, was a frequent finding. 


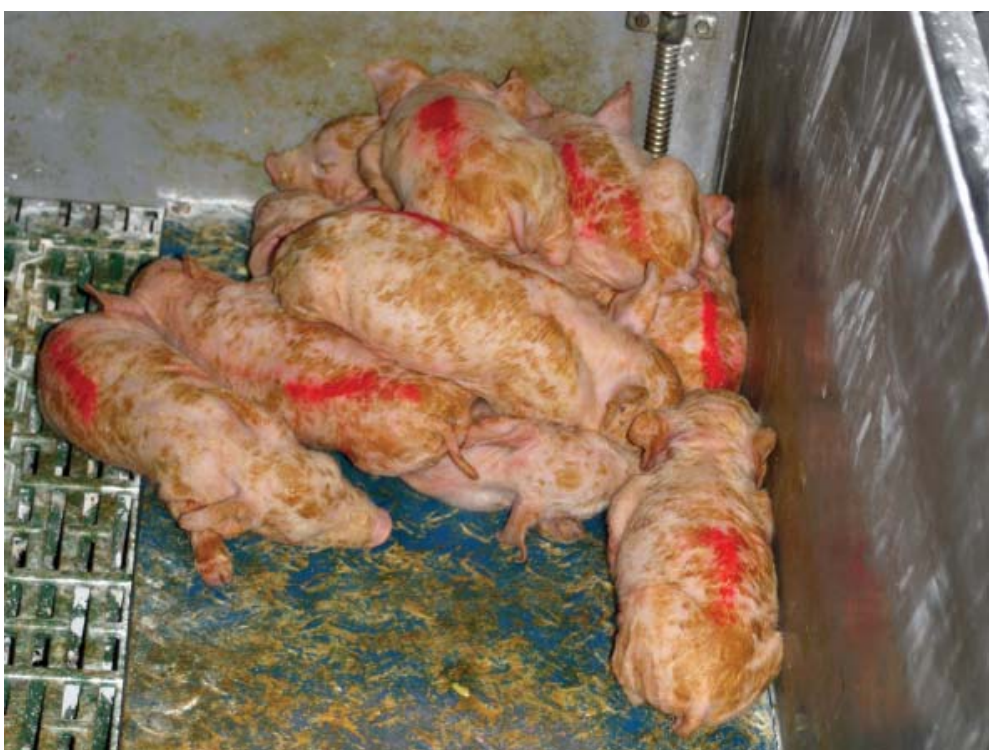

Figure 4. PEDV-infected litter

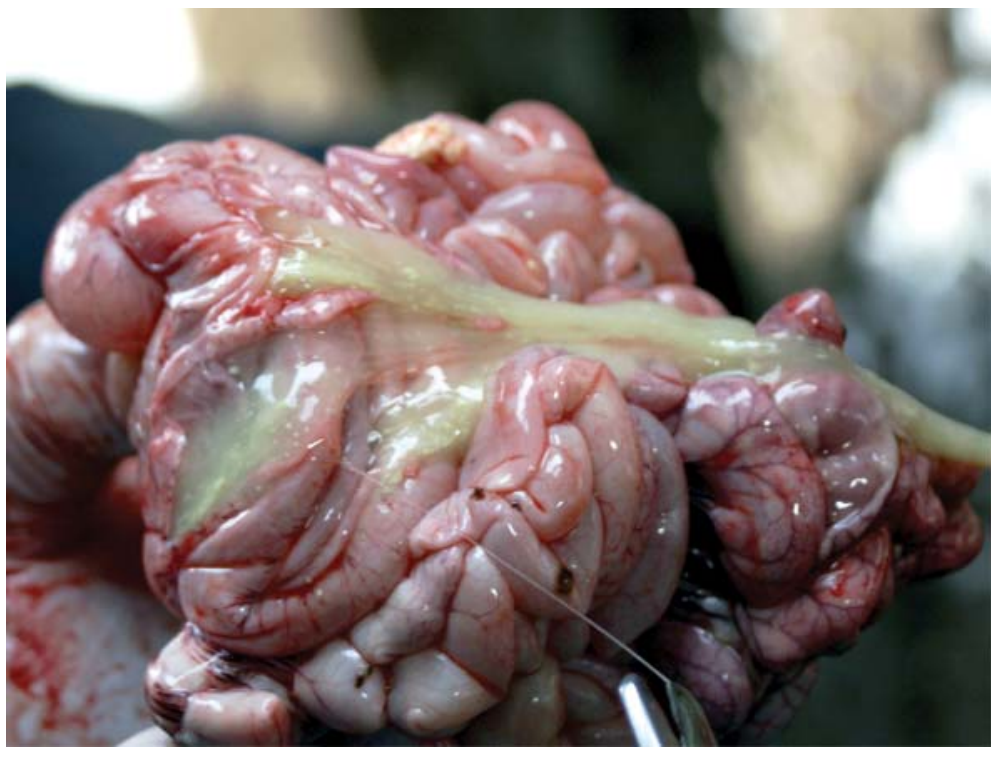

Figure 5. Intestine with fluid, mucoid content

\section{Multiplex RT-PCR}

Results of the conventional multiplex RT-PCR showed that only the samples derived from investigated swine farm $G$ were positive for PEDV. Additionally, the PCR positive reaction on PEDV was confirmed by sequencing (results not shown). The PEDV positive samples were negative for rotavirus group A and TGEV (Figure 6). 
Also, the examined samples from other investigated swine farms (A, B, C, D, E, F) were negative for TGE and rotavirus $\mathrm{A}$.

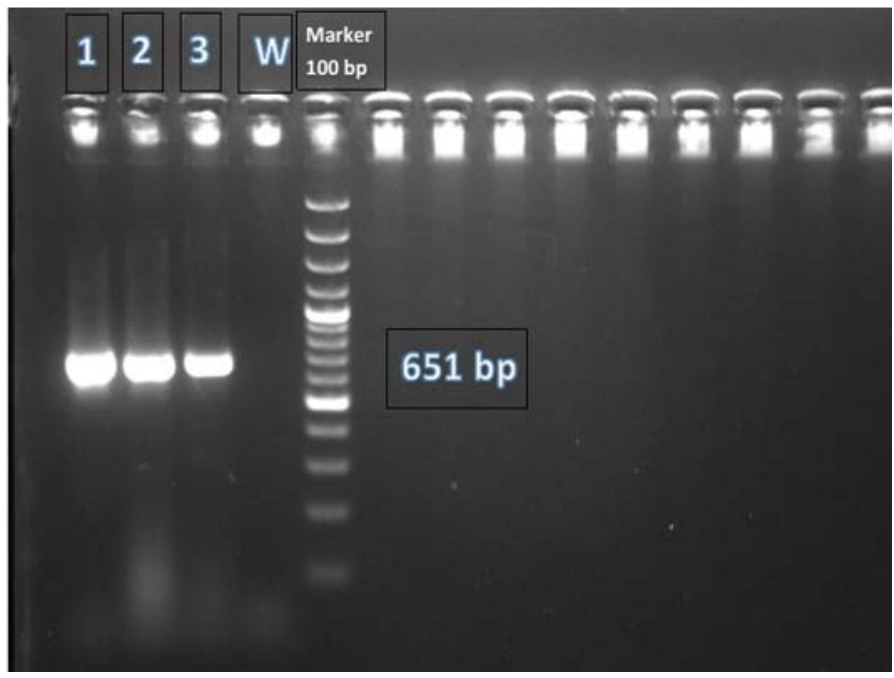

Figure 6. Products of multiplex PCR on samples from PEDV positive farm on $1.5 \%$ agarose gel. From left to right: samples 1 and 2 are the first sample in duplicate, and sample 3 is the second sample from PEDV positive farm. W - negative control; and Marker $100 \mathrm{bp}$. The PCR band of $641 \mathrm{bp}$ presents the part of $\mathrm{S}$ gene of PEDV.

\section{DISCUSSION}

In this study, the samples from seven farrow-to-finish swine farms were tested on the presence of the most prevalent viral enteric diseases of swine (PEDV, TGE, rotavirus A) $[1,8]$. Only samples from one farm, where an outbreak of severe watery diarrhea and vomiting in all swine categories was detected in January of 2016, were positive for PEDV. On the affected swine farm, the first diagnosis of PED was made after clinical and post-mortem examination of affected piglets.

Field observations in the USA in 2013 [24] suggest that the incubation period of PEDV before the appearance of clinical signs varies, ranging from 1 to 7 days (USA PEDV) or 5-8 days (UK PEDV) [2,6]. The virus replicates in the cytoplasm of the enterocytes of the small intestine and causes villous shortening and reduced enzymatic and absorptive capacity causing profuse watery diarrhea [5]. The clinical signs which are frequently associated to PEDV infection include vomiting, anorexia and weight loss. The severity of clinical signs and mortality appeared to be inversely related to the age of the pigs. In weaner to finisher pigs, including pregnant sows, clinical signs are self-limiting within 5-10 days after the onset of the disease [16]. The severity of PED is the highest in suckling piglets of less than one week of age which may die due to severe dehydration [2,6]. The slower turnover of enterocytes in neonatal piglets (5-7 days) compared to three weeks-old piglets (2-3 days) could explain the higher 
susceptibility of young piglets to PEDV [1,2,6]. The impaired gut integrity might lead to loss of water into the intestinal lumen with high osmotic pressure, as well as to the uptake of luminal bacteria causing co-infections [16]. In PEDV infection, gross lesions are limited to the gastrointestinal tract and are characterized by thin and transparent intestinal walls with accumulation of large amounts of yellow fluid in the intestinal lumen [24]. Mortality can reach up to $80-100 \%$ in suckling piglets under one week of age, while in weaned pigs mortality rate is typically only 1 to $3 \%$. No mortality associated with PED is usually observed among adult pigs $[4,13]$. The epidemic outbreaks frequently occur when PEDV is introduced into a naïve farm and the disease spreads rapidly affecting pigs of all ages. Moreover, PEDV can persist and become endemic on the farm affecting post-weaning piglets that have lost their lactogenic immunity as well as newly introduced seronegative gilts [4,5,24].

Onset of PED following introduction of feeder pigs and rapid spread within the farms were reported from several recent outbreaks in Germany and Austria [15,17]. In comparison to our findings, the PED report from Austria was characterized by a mild enteric disease that resolved within 3 days, with no observed mortality [17]. High morbidity, but low or no mortality among fattening pigs was also recorded during PED epidemic 2005-2006 in Italy [16]. In contrast, highly varying degrees of mortality (6-68\%) among suckling and weaned piglets were observed on German sow farms and on a French farrow-to-finish herd [15,18]. Differences in the virulence of PEDV isolates may possibly explain this variability [13]. It has been suggested that circulating viruses within European countries are genetically similar to the INDEL strains found in the USA and China [9]. These viruses caused less severe signs than the non-INDEL strains [13]. Moreover, the PEDV isolates recovered in European countries (Germany, Italy, Belgium, Netherlands and France) in 2014 and 2015 have been characterized and all of them were found to be INDEL isolates similar to the variant described in the USA [3,12]. However, PEDV isolates recently recovered in outbreaks of PEDV in Ukraine have shown a genome nucleotide similarity reaching $99.8 \%$ with non-INDEL isolates from the USA. So far, this has been the only report of PEDV non-INDEL isolates in Europe [20].

Once a diagnosis of PEDV was confirmed, a further investigation was conducted to identify possible routes of viral entry. The main question was the origin of the virus and how the virus entered the farm. Information regarding dates corresponding to the period of time between delivery of feed and onset of clinical signs were analyzed. In addition, all transport-related activities, data pertaining to recent genetic introductions, and records of personnel and supply entry on a farm were reviewed. According to farm history data, in the beginning of January 2016, there was an extensive transport of the fatteners from the farm to different slaughterhouses in the region. The main suspicion referred to the transport of pigs to slaughterhouse facilities in vehicles that entered the farm perimeter, but have not been cleaned and disinfected between the loads in different locations. The main problem was the fact that transport vehicles entered directly the farm perimeter, very close to the unit with growers and fatteners. 
Direct and indirect PEDV transmission occurs mainly by fecal-oral route [10,14]. Viral shedding in feces starts on post-infection day (dpi) one or two and continues for a period of 7-10 days, although it can be extended up to 36 weeks in some animals. The transmission of the infection is facilitated by the high viral load in the feces from infected animals, as well as by the minimum infectious dose required to infect naïve pigs $[1,14,24]$. In the studied case, the primary hypothesis was that contaminated, not adequately cleaned and disinfected trucks before entering transferred the virus into examined swine farm. Similarly, the transport process has been shown to be a source of transmission of PEDV in the USA. In the study of Lowe et al. [14] it was concluded that transportation equipment for moving pigs from farms to slaughterhouse facilities had a significant role in the spreading of PEDV. Moreover, the resistance of the virus under low temperatures in the environment facilitates the indirect transmission by different feces-contaminated fomites such as transport vehicles, clothing or footwear $[14,24]$. It should be emphasized that on the investigated farm, change of clothing between different stables was not practiced. The environmental viral load was reduced by everyday cleaning and intensive disinfection of the area, euthanasia of neonatal piglets, and reduction of transmission by humans and other vectors through enhanced internal biosecurity measures. Since PEDV has not been reported on other swine farms in Serbia, the main source of infection remains unknown. Taking in consideration all the data, PEDV was most likely introduced in the farm by transport vehicles from an unknown source, probably even outside Serbia.

There is no specific treatment for PEDV other than supportive care and symptomatic treatment $[1,6]$. Mortality occurs in suckling piglets as a result of dehydration which should be corrected by using oral electrolyte solutions [24]. Piglets are protected against PEDV by specific antibodies from the colostrum of immune sows until they are 4 to 13 day old $[4,10]$. In order to increase passive immunity to piglets, sows due to farrow in at least 2 weeks can be deliberately exposed to the virulent autogenous virus by the oral route $[5,20]$. It is considered that the interval between onset and cessation of the disease is generally 3-4 weeks; however clinical signs mainly develop in the seronegative lactating sows and their suckling piglets [13,24]. However, the intestinal contents may not have homogenous titres of PEDV and the induction of solid lactogenic immunity might not be as expected $[2,4,6]$. Also, there is a potential risk of incidental widespread infection of other pathogenic viruses, such as porcine circovirus type 2 (PCV2), contained in the PEDV-infected piglets' faeces or intestines among sows or their suckling piglets via vertical transmission routes [1,2]. In our research, the lactogenic immunity was successfully initiated by deliberate re-exposure of pregnant sows to infected feces or minced intestines from infected neonatal piglets 6 weeks before farrowing. It should be emphasized that pig vaccination against classical swine fever (CSF) is obligatory in Serbia and the significance of colostrum intake for effective passive immunity against (CSF) is undoubtable. In the presented PED outbreak, CSF passive immunity impairment due to inadequate colostrum intake in survived suckling piglets should be taken under consideration in the future. 
Direct detection of PEDV in fecal samples by conventional or real-time PCR, are the most frequent assays used at present $[4,23]$. The detection of PEDV specific antibodies may be useful in the future, not for the investigation of diarrhea outbreaks, but to determine whether an animal or a herd has previously been infected by this virus [5]. Several PEDV vaccines, which differ in their genomic sequence, mode of delivery and efficacy have been developed [2,6]. However, in Europe, the disease caused by PEDV was not of sufficient economic importance to start the vaccine usage [4,5]. As there are no specific treatments for the control and potential eradication of the disease from the herd, preventive measures which preclude the introduction of the virus or new PEDV strains in the country or farm are of paramount importance. At herd level, the basic external biosecurity rules (quarantine, forbidden entrance of unwashed vehicles, strict visitor policies) should be carried out without exception $[1,5,6]$.

\section{CONCLUSION}

The clinical signs, in conjunction with the gross pathology lesions seen and laboratory test results allowed us to conclude this was the first documented and confirmed case of PED in Serbia. This PED outbreak showed clinical characteristics similar to outbreaks caused by virulent strains of PEDV reported recently from EU countries. However, we studied only in total seven swine farms and this may not reflect the actual situation of this pig infection in the country. In Serbia, there is no active surveillance scheme for PEDV, hence we cannot state with confidence that PEDV has not been circulating in other parts of the country. The origin of this PEDV still needs to be elucidated and further investigations may contribute to the knowledge.

\section{Acknowledgements}

This work was supported by the Ministry of Science and Technological Development of the Republic of Serbia, grants TR 31084.

\section{Authors' contributions}

JPR detected the first signs of disease and carried epidemiological and clinical investigation. PT and LD carried out the molecular genetic studies (molecular detection and characterisation), and drafted the manuscript. MD was involved in clinical investigation and sampling procedure. LS participated in the epidemiological data analysis. GŽ participated in the design of the study and performed the data analysis. PJ conceived of the study, and participated in its design and coordination and helped to draft the manuscript. All authors have read and approved the final version of manuscript. 


\section{Declaration of conflicting interests}

The author(s) declared no potential conflicts of interest with respect to the research, authorship, and/or publication of this article.

\section{REFERENCES}

1. Saif LJ, Pensaert MB, Sestak K, Yeo SG, Jung K: Coronaviruses. In: Diseases of Swine. Oxford, United Kingdom: Blackwell Publishing; 2012, 501-524.

2. Jung $\mathrm{K}$ and Saif LJ: Porcine epidemic diarrhea virus infection: Etiology, epidemiology, pathogenesis and immunoprophylaxis. Vet. J. 2015, 204:134-143.

3. Jarvis MC, Lama HC, Zhangb Y, Wangb L, Hessec RA, Hausec BM, Vlasovad A, Wangd Q, Zhange J, Nelson MI, Murtaughg MP, Marthalera D: Genomic and evolutionary inferences between American and global strains of porcine epidemic diarrhea virus. Prev. Vet. Med. 2016, 123: 175-184.

4. Song D and Park B: Porcine epidemic diarrhoea virus: a comprehensive review of molecular epidemiology, diagnosis, and vaccines. Virus Genes 2012, 44:167-175.

5. Carvajal A, Argüello H, Martínez-Lobo FJ, Costillas S, Miranda R, de Nova PJG, Rubio P: Porcine epidemic diarrhoea: new insights into an old disease. Porcine Health Management 2015, 1:12.

6. Song D, Moon H, Kang B: Porcine epidemic diarrhea: a review of current epidemiology and available vaccines. Clin Exp Vaccine Res 2015; 4:166-176.

7. Mesquita JR, van der Honing RH, Almeida A, Lourenco M, van der Poel WHM, Nascimento MSJ: Outbreak of Porcine Epidemic Diarrhea Virus in Portugal, 2015. Transboundary and Emerging Diseases 2015, 62:586-588

8. Nagy B, Nagy GY, Meder M, Mocsári E.: Enterotoxigenic Escherichia coli, Rotavirus, Porcine Epidemic Diarrhoea Virus, Adenovirus and Calici-like virus in porcine postweaning diarrhoea in Hungary. Acta Vet. Hung. 1996, 44 (1): 9-19.

9. Hanke D, Jenckel M, Petrov A, Ritzmann M, Stadler J, Akimkin V, Blome S, Pohlmann A, Schirrmeier H, Beer M, Hoper D. Comparison of porcine epidemic diarrhea viruses from Germany and the United States, 2014. Emerg. Infect. Dis. 2015, 21: 493-496.

10. Sun R, Leng Z, Dekun C, Song C: Multiple Factors Contribute to Persistent Porcine Epidemic diarrhea Infection in the Field: An Investigation on Porcine epidemic Diarrhea Repeated Outbreaks in the Same Herd. J ANIM VET ADV 2014, 13(6):410-415.

11. Carvajal A, Lanza I, Diego R, Rubio P, Cármenes P. Seroprevalence of porcine epidemic diarrhea virus infection among different types of breeding swine farms in Spain. Prev. Vet. Med. 1995, 23: 33-40.

12. Chen Q, Li G, Stasko J, Thomas JT, Stensland WR, Pillatzki AE, Gauger PC, Schwartz KJ, Madson D, Yoon KJ, Stevenson GW, Burrough ER, Harmon KM, Main RG, Zhang $\mathrm{J}$ : Isolation and characterization of porcine epidemic diarrhea viruses associated with the 2013 disease outbreak among swine in the United States. J.Cli.Microbiol. 2014, 52:234-243.

13. Wang L, Byrum B, Zhang Y: New variant of porcine epidemic diarrhea virus, United States. Emerg. Infect. Dis. 2014, 20:917-919. 
14. Lowe J, Gauger P, Harmon K, Zhang J, Connor J, Yeske P, Loula T, Levis I, Dufresne L, Main R: Role of Transportation in Spread of Porcine Epidemic Diarrhea Virus Infection, United States. Emerg. Infect. Dis. 2014, 20:872-874.

15. Stadler J, Zoels S, Fux R, Hanke D, Pohlmann A, Blome S, Weissenböck H, WeissenbacherLang C, Ritzmann M, Ladinig A: Emergence of porcine epidemic diarrhea virus in southern Germany. BMC Veterinary Research 2015, 11:142.

16. Martelli P, Lavazza A, Nigrelli AD, Merialdi G, Alborali LG, Pensaert MB: Epidemic of diarrhoea caused by porcine epidemic diarrhea virus in Italy. Vet Rec. 2008, 162 (10): 307310.

17. Steinrigl A, Fernández SR, Stoiber F, Pikalo J, Sattler T, Schmoll F: First detection, clinical presentation and phylogenetic characterization of Porcine epidemic diarrhea virus in Austria. BMC Veterinary Research 2015, 11:310.

18. Grasland B, Bigault L, Bernard C, Quenault H, Toulouse O, Fablet C, Rose N, Touzain F, Blanchard Y: Complete Genome Sequence of a Porcine Epidemic Diarrhea S Gene Indel Strain Isolated in France in December 2014. Genome Announc. 2015, 3:3.

19. Theuns S, Conceiçăo-Neto N, Christiaens I, Zeller M, Desmarets L, Roukaerts I, Acar DD, Heylen E, Matthijnssens J, Nauwynck HJ: Complete Genome Sequence of a Porcine Epidemic Diarrhea Virus from a Novel Outbreak in Belgium, January 2015. Genome Announc. 2015, 3:3.

20. Dastjerdi A, Carr J, Ellis RJ, Steinbach F, Williamson S: Porcine Epidemic Diarrhea Virus among Farmed Pigs, Ukraine. Emerg. Infect. Dis. 2015, 21(12): 2235-2237.

21. Boniotti MB, Papetti A, Lavazza A, Alborali G, Sozzi E, Chiapponi C, Faccini S, Bonilauri P, Cordioli P,Marthaler D: Porcine Epidemic Diarrhea Virus and Discovery of a Recombinant Swine Enteric Coronavirus, Italy. Emerg. Infect. Dis. 2016, 22 (1): 83-87.

22. Toplak I, Ipavec M, Kuhar U, Kušar D, Papic B, Koren S, Toplak N: Complete Genome Sequence of the Porcine Epidemic Diarrhea Virus Strain SLO/JH-11/2015. Genome Announc 2015, 4:2.

23. Song DS, Kang BK, Oh JS, Ha GW, Yang JS, Moon HJ, Jang J-S, Park BK: Multiplex reverse transcription-PCR for rapid differential detection of porcine epidemic diarrhea virus, transmissible gastroenteritis virus, and porcine group A rotavirus. J Vet Diagn Invest 2006, 18:278-281.

24. Stevenson GW, Hoang H, Schwartz KJ, Burrough ER, Sun D, Madson D, Cooper VL, Pillatzki A, Gauger P, Schmitt BJ, Koster LG, Killian ML, Yoon KJ: Emergence of Porcine epidemic diarrhea virus in the United States: clinical signs, lesions, and viral genomic sequences. J Vet Diagn Invest 2013, 25(5): 649-654.

\title{
KLINIČKA MANIFESTACIJA I PRVA DETEKCIJA VIRUSNOG EPIDEMIČNOG PROLIVA SVINJA U SRBIJI
}

\author{
PRODANOV-RADULOVIĆ Jasna, PETROVIĆ Tamaš, LUPULOVIĆ Diana, \\ MARČIĆ Doroteja, PETROVIĆ Jelena, GRGIĆ Živoslav, LAZIĆ Sava
}

Tokom 2015/2016 godine, na ukupno sedam farmi svinja sa proizvodnim ciklusom od prašenja do tova na severu Srbije (region Vojvodine), vršeno je uzorkovanje fecesa i creva poreklom od živih obolelih i/ili uginulih svinja, kod kojih je postavljena sum- 
nja na infekciju svinja virusom epidemičnog proliva i/ili transmisivnog gastroenteritisa kao i rotavirusne infekcije. Ukupno je laboratorijski ispitano 14 uzoraka (2 zbirna uzorka po jednoj farmi) tankih creva sa fekalnim sadržajem molekularnom metodom (multipleks RT-PCR). Na ispitivanim farmama klinički znaci bolesti su obuhvatali pojavu proliva prasadi na sisi i zalučene prasadi, sa slabim ili izostankom očekivanog poboljšanja na primenjenu antimikrobnu terapiju. Epidemija teške dijareje koja je obuhvatila sve uzrasne kategorije svinja je utvrđena na jednoj farmi u januaru 2016. godine. Kod svih kategorija je utvrđena vodenasta dijareja, udružena sa povraćanjem i umanjenjom konzumacijom hrane. Proliv, mršavljenje dehidratacija prasadi i koža prekrivena fecesom su ustanovljeni u 90\% legala. Oboljenje je bilo najizraženije kod prasadi na sisi, i mortalitet novorođene prasadi je bio do $35 \%$. Kod zalučene prasadi i tovljenika moratlitet je bio do 2,5\% odnosno 1,2\%. Nukleinska kiselina virusa epidemične dijareje je utvrđena u zbirnim uzorcima fecesa i tankih creva poreklom od obolele i uginule prasadi na sisi samo na jednoj ispitanoj farmi. Navedeni uzorci su bili negativni na virus transmisivnog gastroenteritisa kao i rotavirus A. Transportna vozila su označena kao najverovatniji put unošenja virusa epidemičnog proliva na farmu. Ovo je prva potvrda prisustva virusa epidemičnog proliva svinja u Srbiji. 